\title{
No definitive conclusion as to the most effective method of pulp treatment of asymptomatic carious teeth
}

\author{
How effective are the different pulp management techniques used to treat \\ asymptomatic carious teeth and maintain pulp vitality?
}

\author{
Miyashita H, Worthington HV, Qualtrough A, Plasschaert A. \\ Pulp management for caries in adults: maintaining pulp vitality. \\ Cochrane Database Syst Rev 2007; issue 2
}

Data sources The Cochrane Oral Health Group's Trials Register, Cochrane Central Register of Controlled Trials, Medline, Embase, National Research Register and the Science Citation Index SCISEARCH were searched. Key journals were searched by hand, together with reference lists of review articles and endodontic textbooks. There was no language restriction.

Study selection Randomised controlled trials (RCT) or quasi-RCT were included that compared techniques to maintain pulp vitality of asymptomatic permanent teeth with extensive caries. Outcome measures included clinical success and adverse events.

Data extraction and synthesis Data were independently extracted by three review authors and, where necessary, further information was sought from the author. The quality of included studies was assessed using standard criteria.

Results The search identified 34 studies of which four met the inclusion criteria. Interventions examined included: Ledermix $®($ Wyeth Lederle, Denmark), glycerrhetinic acid/ antibiotic mix, zinc oxide eugenol, calcium hydroxide, Cavitec ${ }^{\circledR}($ Kerr Corporation, Orange, CA 92867), Life ${ }^{\circledR}\left(D E N T S P L Y\right.$ Caulk, Milford, DE 19963-0359), Dycal ${ }^{\circledR}$ (DENTSPLY Caulk, Milford, DE 19963-0359)potassium nitrate, dimethyl isosorbide, and polycarboxylate cement. Only one study produced a statistically significant finding: potassium nitrate/ dimethyl isosorbide/ polycarboxylate cement resulted in fewer clinical symptoms than potassium nitrate/ polycarboxylate cement or polycarboxylate cement alone when used as a capping material for carious pulps.

Conclusions The findings of this review suggest that there should not be any significant change from accepted conventional practice procedures when the pulp of the carious tooth is considered. Further well-designed RCT are needed to investigate the potential of contemporary materials which may be suitable when used in the management of carious teeth.

Address for correspondence: Alison Qualtrough, School of Dentistry,

University of Manchester, Higher Cambridge Street, Manchester M15 6FH, UK.

Email: alison.qualtrough@manchester.ac.uk

\section{Commentary}

For over 50 years, it has been suggested that the application of a liner to an exposed or nearly exposed pulp chamber may prevent irreversible damage to the endodontic complex. ${ }^{1}$ There seems to be no agreement in dentistry, however, on what is the standard of care for the management of a deep carious lesion. ${ }^{2}$ This systematic review attempted to eliminate this confusion by generating the highest level of clinical evidence - a systematic review of all existing RCT.

The review's authors searched all major health science databases but, although many significant dental journals were searched by hand, the Journal of Dental Research was omitted from the list. It is possible that relevant studies were missed since the concept of pulp capping was first described by Zane in that journal in $1939 .^{3}$ There was also no mention of reviewing Current Clincal Trials (http://www.controlled-trials.com/) and ClinicalTrials.gov (http:// clinicaltrials.gov/ct/gui/c/b ) databases for any registered RCT on this topic. This may have provided valuable data for a meta-analysis, as well as giving an indication of any pending RCT dealing with this issue. Nevertheless, these minor comments are compensated for by a clearly presented review with a rigorously performed methodology and analysis.

Disappointingly, the review was unable to make any firm clinical recommendation on the pulp capping requirements for managing deep carious lesions. Although one study did show a statistically significant outcome for isosorbide when used in conjunction with potassium nitrate and polycarboxylate cements as a direct pulp capping liner, its small sample size prevents its being generalised to clinical practice. In addition, the lack of homogeneity between the four studies that met the inclusion criteria prevented the reviewers from carrying out a valid meta-analysis. Regardless, the studies reviewed infer a generally favourable prognosis (ie, 70-90\% after 1 year) following the pulp capping technique (Table 1 ).

None of these studies had a non-liner control group for comparison so we are still not sure if a liner is necessary for the pulp to recover from the excavation of a deep carious lesion. This may be a moot point since dentine-bonded lining has become ubiquitous in restorative dentistry. Nevertheless, the use of any other lining material for pulp capping (ie, calcium hydroxide) prior to dentin bonding may not be necessary.

Confusion continues regarding the mechanism that liners play in pulp tissue recovery. Some people argue that sealing the endodontic complex from further bacterial ingress allows pulpal recovery and then some sort of chemical initiator in the pulp liner promotes healing. ${ }^{8-10}$ As a clinician, this is important to know, especially in the clinical scenario when caries excavation causes a direct pulp exposure.

What needs to be established, therefore, is what type of pulp-capping lining material (if any) is necessary to trigger any potential pulp 
Table 1. Summary of studies included in review

\begin{tabular}{|c|c|c|c|c|c|c|}
\hline Study & Successful outcome & $\begin{array}{l}\text { Follow-up } \\
\text { (months) }\end{array}$ & $\begin{array}{l}\text { Caries } \\
\text { management }\end{array}$ & Liners & Teeth (n) & $\begin{array}{l}\text { Success } \\
\text { rates*(\%) }\end{array}$ \\
\hline \multirow{4}{*}{$\begin{array}{l}\text { Shovelton et al. } \\
(1971)^{4}\end{array}$} & \multirow{4}{*}{$\begin{array}{l}\text { Asymptomatic and no } \\
\text { clinical signs }\end{array}$} & \multirow{4}{*}{24} & \multirow{4}{*}{ Direct } & Ledermix & 36 & 77.7 \\
\hline & & & & Glycerrhetinic acid & 38 & 73.7 \\
\hline & & & & $\mathrm{Ca}(\mathrm{OH})_{2}$ & 41 & 78.0 \\
\hline & & & & ZOE & 39 & 69.2 \\
\hline \multirow{7}{*}{$\begin{array}{l}\text { Fitzgerald \& } \\
\text { Heys }(1991)^{5}\end{array}$} & \multirow{7}{*}{ Asymptomatic } & \multirow{7}{*}{12} & \multirow{2}{*}{ Indirect } & Life & 22 & 81.8 \\
\hline & & & & Dycal & 24 & 87.5 \\
\hline & & & \multirow{3}{*}{$\begin{array}{l}\text { Compete caries } \\
\text { removal }\end{array}$} & Life & 14 & 92.9 \\
\hline & & & & Dycal & 18 & 83.3 \\
\hline & & & & Cavitec & 14 & 100 \\
\hline & & & \multirow{2}{*}{ Direct } & Life & 4 & 50 \\
\hline & & & & Dycal & 4 & 100 \\
\hline \multirow{3}{*}{$\begin{array}{l}\text { Hodosh et al. } \\
(2003)^{6}\end{array}$} & \multirow{3}{*}{$\begin{array}{l}\text { Absence of periapical } \\
\text { pathology, tenderness to } \\
\text { pressure fistula formation }\end{array}$} & \multirow{3}{*}{24} & \multirow{3}{*}{ Direct } & $\mathrm{KNO}_{3} / \mathrm{DMI} / \mathrm{PCa}$ & 18 & $100^{\dagger}$ \\
\hline & & & & $\mathrm{KNO}_{3} / \mathrm{PCa}$ & 17 & 47.0 \\
\hline & & & & $\mathrm{PCa}$ & 12 & 16.7 \\
\hline \multirow[b]{2}{*}{$\begin{array}{l}\text { Whitworth } \\
\text { et al. }(2005)^{7}\end{array}$} & \multirow[b]{2}{*}{$\begin{array}{l}\text { Pain scores on a VAS; teeth } \\
\text { not requiring extraction or } \\
\text { root canal therapy }\end{array}$} & \multirow[b]{2}{*}{36} & \multirow[b]{2}{*}{ Not clear } & $\mathrm{Ca}(\mathrm{OH})_{2}$ & 288 & \multirow[b]{2}{*}{$\begin{array}{l}\text { Unable to } \\
\text { calculate }\end{array}$} \\
\hline & & & & $\begin{array}{l}\text { Etch/ prime and seal } \\
\text { with commercial } \\
\text { bonding agent }\end{array}$ & 314 & \\
\hline
\end{tabular}

ZOE, zinc oxide eugenol; DMI, dimethyl isosorbide; PCa, polycarboylate cement; VAS, visual analogue scale.

*Success rates calculated by B. Balevi from presented data.

†Statistically significant $\mathrm{P}<0.05$

†Not reported how many of the total 323 teeth lost to follow-up after 3 years were from each treatment group. Six in the $\mathrm{Ca}(\mathrm{OH})_{2}$ group and 10 in bonding agent liner group underwent root canal therapy within the 3-year follow-up.

recovery from the excavation of a deep carious lesion and then to determine the most reliable approach (direct, indirect, or remove all caries regardless of risk to exposure). An answer to such a relevant clinical question can only be realised by following the reviewers' recommendations - more well-conducted RCT.

\section{Ben Balevi}

\section{Dental Practitioner, Vancouver, British Columbia, Canada.}

1. Bergenholtz G. Advances since the paper by Zander and Glass (1949) on the pursuit of healing methods for pulpal exposures: historical perspectives. Oral Surg Oral Med Oral Pathol Oral Radiol Endod 2005; 100 (suppl.):S102-S108.

2. Oen KT, Thompson VP, Vena D, et al.: Attitudes and expectations of treating deep caries: a PEARL network survey. Gen Dent 2007; 55:197-203.

3. Zane H. Reaction of the pulp to calcium hydroxide. J Dent Res $1939 ; 18: 373-379$.
4. Shovelton DS, Friend LA, Kirk EE, Rowe AH. The efficacy of pulp capping materials. A comparative trial. Br Dent J 1971; 130:385-391.

5. Fitzgerald M, Heys RJ. A clinical and histological evaluation of conservative pulpal therapy in human teeth. Oper Dent 1991; 16:101-112.

6. Hodosh M, Hodosh SH, Hodosh AJ. Capping carious exposed pulps with potassium nitrate dimethyl isosorbide, polycarboxylate cement. Dent Today 2003 :22:46-51.

7. Whitworth JM, Myers PM, Smith J, Walls AW, McCabe JF. Endodontic complications after plastic restorations in general practice. Int Endod J 2005; 38:409-416.

8. Qudeimat MA, Barrieshi-Nusair KM, Owais Al. Calcium hydroxide vs mineral trioxide aggregates for partial pulpotomy of permanent molars with deep caries. Eur Arch Paediatr Dent 2007; 8:99-104.

9. Crane LE. Hard tissue barrier formation after pulp capping? Evid Based Dent 2006; 7:95.

10. Silva GA, Lanza LD, Lopes-Junior N, Moreira A, Alves JB. Direct pulp capping with a dentin bonding system in human teeth: a clinical and histological evaluation. Oper Dent 2006, 31:297-307.

Evidence-Based Dentistry (2007) 8, 5-6. doi:10.1038/sj.ebd.6400508 